DOI:10.17951/h.2019.53.3.53-60

\begin{tabular}{lc}
\hline & A N N A L E S \\
UNIVERSITATIS MARIAE CURIE-SKŁODOWSKA \\
LUBLIN - POLONIA \\
SOL. LIII, 3 & SECTIO H \\
\hline
\end{tabular}

\author{
SEBASTIAN SUSMARSKI \\ sebastian.susmarski@ug.edu.pl \\ University of Gdańsk, Faculty of Management \\ 101 Armii Krajowej St, 81-824 Sopot, Poland \\ ORCID ID: https://orcid.org/0000-0003-2871-1720
}

\title{
The use of stakeholder analysis in assessing the effectiveness of selected functions of the Gdańsk Science and Technology Park
}

Keywords: stakeholder theory; stakeholder classification; stakeholder management; infrastructure projects

JEL: D78; H76; R53

How to quote this paper: Susmarski, S. (2019). The use of stakeholder analysis in assessing the effectiveness of selected functions of the Gdańsk Science and Technology Park. Annales Universitatis Mariae Curie-Skłodowska, Sectio H Oeconomia, Vol. 53, No. 3.

\footnotetext{
Abstract

Stakeholder analysis provides relevant information about the organization's impact on the environment and the environment's impact on the organization. These relationships are gaining importance in investment activities, especially in relation to projects that are partly or fully financed from public funds. Stakeholder analysis is therefore a key tool for project managers providing them with knowledge on the best communication strategy with stakeholders that can lead to management of relationships with stakeholders.

The aim of the article is to indicate how much the balance of social benefits and costs perceived by stakeholders regarding the expansion of an innovation centre, the Gdańsk Science and Technology Park (GSTP), contributes to the increase in the value of this project. The study also has partial goals established: the effectiveness of implementing by the GSTP the function of increasing cooperation with universities and the industry in conducting experimental research and subsequently translating these effects into practical applications from the point of view of companies and residents. The key element of the research was to identify the needs of particular groups of stakeholders in the context of choosing methods of communicating with them. The study used a survey conducted among stakeholders of the GSTP.
} 


\section{Introduction}

The problem of assessing the effectiveness of infrastructure investments financed from public funds is the subject of numerous theoretical, methodological, and empirical works. They draw attention to the important role of these investments as a factor of development (Piontek \& Piontek, 2007) shaping the conditions in which local communities function (Kozłowski, 2012). Within the scope of pro-development activities at the local level, investments aimed at creating centres of innovation combining science and business gain special significance.

The aim of the article is to show how much the balance of social benefits and costs perceived by stakeholders and related to the expansion of one of the innovation centres, the Gdańsk Science and Technology Park (GSTP), contributes to the value of this project. In the study, the following partial goals were also established: the effectiveness of implementing by the GSTP the function of increasing cooperation with universities and industry in conducting experimental research and subsequently translating these effects into practical applications from the point of view of companies and residents.

\section{Literature review}

Among the methods of assessing the effectiveness of investment projects present in the theory of economics, it is worth distinguishing the multi-criteria method, cost-effectiveness and cost-benefit analysis (CBA). Particularly noteworthy is the latter, as its use is a prerequisite when applying for funds from the European Union budget. ${ }^{1}$

Publication of the European Commission devoted to the principles of making a cost-benefit analysis in investment projects became a significant methodological facilitation (Florio, 2008; European Commission, 2006). However, the referenced publications clearly lack the consideration of the role and position of stakeholders.

During the implementation of infrastructure projects, especially those in which public funds are used, various groups of entities (stakeholders) are present: they are influenced by the projects and their impact on the projects can be observed. One of the first definitions of the concept of stakeholders was presented in 1983 by Freeman and Reed, who characterized them as "those groups without whose support the organization would cease to exist" (Freeman \& Reed, 1983). The authors stress the

\footnotetext{
1 By the provisions of the Council Regulation (WE) No. 1083/2006 of 11 July 2006 establishing general provisions regarding the European Regional Development Fund, the European Social Fund and the Cohesion Fund, Member States applying for co-financing projects have to submit to the Commission, among other things: information on the entity responsible for the implementation of projects, information on the nature of the investment and its description, financial value and location, results of the feasibility study, as well as a cost-benefit analysis, including risk assessment and anticipated impact on a given sector and the socioeconomic situation of the Member State or region (possibly on other regions of the Union).
} 
activity of stakeholders for an organization; however, it should be remembered that there is a whole sphere of stakeholders influenced by the organization, therefore, Freeman has made some modification of the concept indicating that stakeholders are "any group or individual who can affect or is affected by the achievement of the organization's objectives" (Freeman, 1984). These aforementioned definitions apply to a broad view, taking into account the functioning of the whole organization, so it is worth narrowing the scope of impact of stakeholders to a specific project. In this case a stakeholder is "a person or group of people who has a vested interest in the success of a project and the environment within which the project operates" (Olander, 2007). This interest may result in support for the project implementation, but also in extreme cases its delay or even interruption of implementation (Ward \& Chapman, 2008). Since stakeholder attitudes can significantly affect the implementation of projects, it would be worth considering the precise definition of this impact by stakeholder classification.

There are many such classifications in the literature (World Bank, 2006), ranging from internal and external (Rybak, 2007) to solutions based on multiple classification criteria (Savage, Nix, Whitehead, \& Blair, 1991). The most comprehensive classification, based on Freeman's works (Freeman, Harrison, \& Wicks, 2007) was done by Mitchell, who analyzed the importance of stakeholders for the organization by assigning three attributes to them: power, urgency, and legitimacy (Mitchell, Agle, \& Wood, 1997). It is worth emphasizing that the abovementioned attributes will enable one to define both the type of stakeholder and their attitude towards the implementation of the project, as shown in Figure 1.

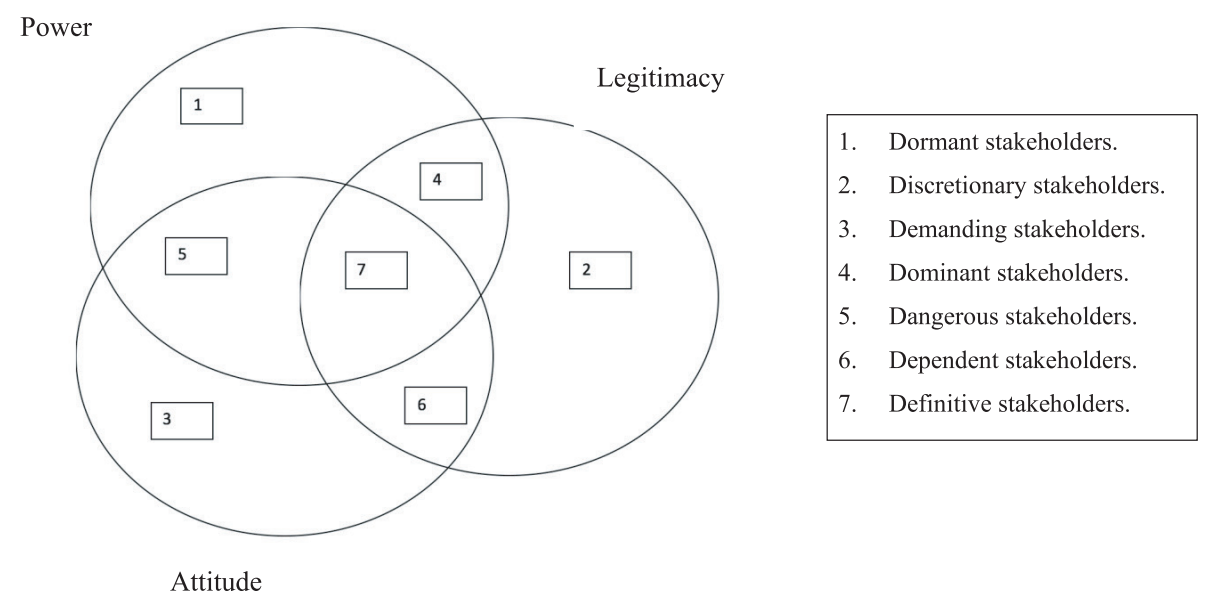

Figure 1. Stakeholder typology based on attributes 


\section{Research method}

The subject of the study was an infrastructural project named "Expansion of the Gdańsk Science and Technology Park. Third stage". The goal of the project was to extend and equip the GSTP with modern laboratory infrastructure. The scope of the project involved the construction of two office and technology buildings with a total area of $29,496 \mathrm{~m}^{2}$. As a result of the project, the GSTP became a large office, production, and technology complex with a total area of approximately $38,000 \mathrm{~m}^{2}$. The main objective of the project was to provide entrepreneurs with high-quality services and infrastructure to strengthen and enable the use of their innovative potential. Additionally, the implementers of the project indicate that the goal was also to create a new quality of products and services and, thus, increase the importance of innovation and advanced technologies as a factor determining economic processes.

The designed procedure requires defining specific aspects of the infrastructure project which are important from the point of view of the research: attributes assigned to each stakeholder, as well as social benefits and costs of stakeholders assigned to this investment. Answers to all survey questions (except for the demographic questions) were rated on a five-point Likert scale. As a result, the survey, i.e. the research tool, consists of the following parts:

1) Answers to demographic survey questions. The information is useful for analyzing the results obtained, such as: sex, age, seniority, distance between the place of living and the place of investment, and the type of stakeholder.

2) A set of questions about stakeholders' attributes: attitude (A), power (P), legitimacy $(\mathrm{L})$, urgency $(\mathrm{U})$. The results obtained allow determination of the attitude of stakeholders towards specific issues.

3) Social benefits and costs, i.e. questions about the social benefits and costs of the implemented infrastructure project.

Social benefits of the extension of the GSTP queried in the survey include:

- creation of new highly specialized jobs;

- rise in the technological potential of the region;

- increase in the implementation of the effects of scientific work;

- increase in the number of patents and inventions;

- elimination of flooding of surrounding areas by modernizing the infrastructure.

Social costs of the extension of the GSTP queried in the survey include:

- increased traffic in the area of the investment;

- increased risk of environmental contamination - activity in the field of biotechnology;

- higher levels of air pollution;

- excessive noise;

- shortage of parking space.

In addition to the above questions, an open question was added, where the surveyed stakeholders could independently indicate a different social benefit or cost 
resulting from the completion of the third stage of GSTP investment. This additional option may help in the subsequent designing of questionnaires regarding the analysis of the benefits and costs of this type of infrastructure project.

Surveys were conducted using a representative sample. The selection of the sample in the research of residents and enterprises was random and layered, taking into account the designated groups of stakeholders. While selecting the sample, the random route technique was used: addresses were randomly chosen and surveys were conducted with people who were present at the company's headquarters. When surveying the GSTP tenants, the study population was made up of employees of companies renting space in the GSTP. In the case of tenants, the study was exhaustive. The total number of tenants was 78 and of that number, 65 tenants agreed to participate in the study. When it comes to the survey among the visitors to the GSTP, the selection of respondents to the sample was incidental. A total of 120 people participated in the research.

\section{Results}

In the survey conducted, stakeholders could assess the five social costs indicated and specify additional benefits that they saw in connection with the implementation of the GSTP expansion project. None of the stakeholders indicated additional benefits. Figure 2 presents the distribution of social benefits from the point of view of the surveyed stakeholder groups. The benefits were ranked with the highest grade by Implementers (majority of answers: "strongly agree").

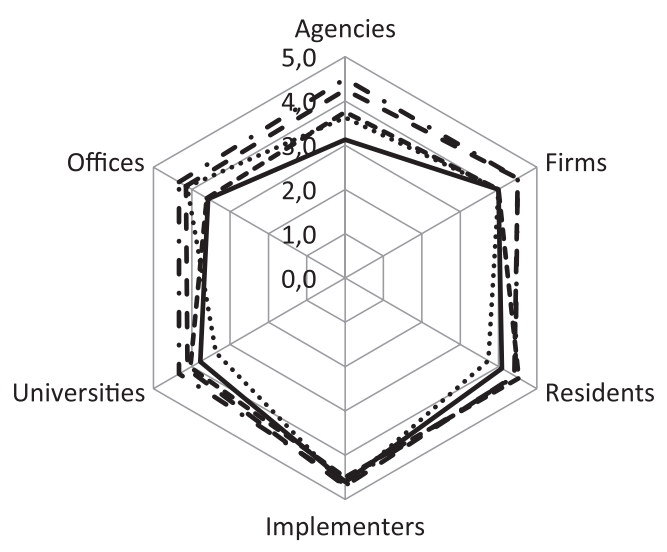

Figure 2. Social benefits of the GSTP extension project

Source: Author's own study.

The other groups of stakeholders marked their answers with "agree". The benefits of creating highly specialized workplaces were rated the highest, while the lowest rankings were given to the increase in the number of patents and inventions. The 
benefits resulting from the rise of the technological potential of the region and the increase in the implementation of the effects of scientific works were also highly evaluated. The benefits resulting from the elimination of flooding of the surrounding areas due to the modernization of the infrastructure were highly appreciated by the Implementers and Offices. Also in the case of questions regarding the social costs of GSTP expansion, the stakeholders did not indicate any additional costs that they would incur in connection with the project and only answered the questions given in the survey. In terms of the social costs, the highest rank was given by the stakeholders to the increased traffic in the area of the investment. Next, all groups excluding Implementers indicated the shortage of parking space. Residents and Offices complained about the excessive noise most. Increased risk of environmental contamination as a result of activity in the field of biotechnology and higher levels of air pollution were selected by Universities, Implementers, and Offices (Figure 3).

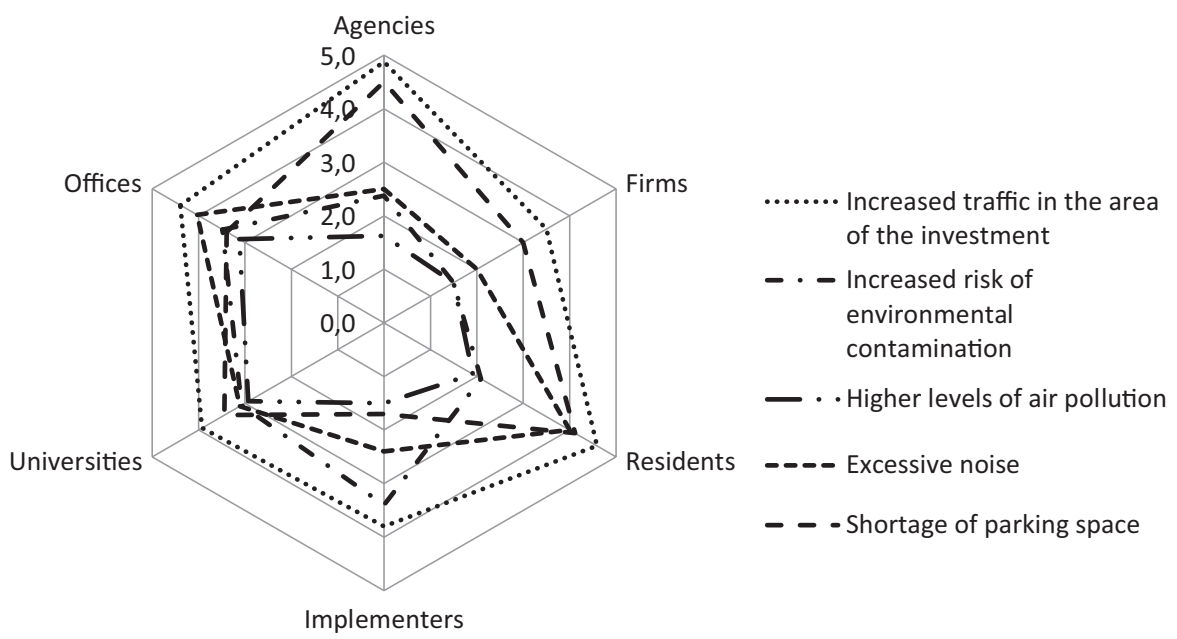

Figure 3. Social costs of the GSTP extension project

Source: Author's own study.

As mentioned above, the indicator of social benefits and costs is determined as a resultant of stakeholders' subjective perception of social benefits and costs of the project and the dependency model between them. Table 1 presents the starting and adjusted values of social benefits and costs of the project analyzed. By analyzing the initial values of social benefits, we can see that the highest are for Implementers (0.75), Firms (0.72), and Agencies (0.68). For all groups of stakeholders, they are high and exceed the value of 0.65 . The initial costs are highest for Residents $(0.62)$, Universities (0.57), and Firms (0.50). After adjusting for weight and calculating average values for the adjusted benefits and costs we get an index of social benefits and costs at the level of $0.06(6 \%)$. This figure indicates that the economic value of the project should be increased by $6 \%$, taking into account the social benefits and 
costs described. The project profitability analysis carried out at the stage of the project feasibility study based on the financial discounted value of cash flows showed that the financial net present value of the investment was PLN -115,987,487 (FNPV/C), while the financial net present value of the capital was PLN -25,085 (FNPV/K).

Table 2 shows the average values of attributes and social benefits perceived by the stakeholders. All stakeholder groups had a very good or good attitude to the expansion of GSTP. When it comes to power, understood as the possibility of an effective impact on the project, the greatest one was demonstrated by the Implementers and Agencies. The remaining four groups of stakeholders surveyed indicated that they did not have the ability to influence the implementation of the project.

Table 1. Indicators of social benefits and costs

\begin{tabular}{|l|c|c|c|c|c|c|}
\hline \multirow{2}{*}{ Stakeholder } & \multicolumn{2}{|c|}{ Starting } & \multirow{2}{*}{ Weight } & \multicolumn{2}{|c|}{ Adjusted } & \multirow{2}{*}{ Difference } \\
\cline { 2 - 3 } & Benefits & Costs & & Benefits & Costs & \\
\hline Agencies & 0.68 & 0.38 & 0.17 & 0.11 & 0.06 & 0.009 \\
\hline Firms & 0.72 & 0.50 & 0.29 & 0.21 & 0.15 & 0.031 \\
\hline Residents & 0.66 & 0.62 & 0.17 & 0.11 & 0.10 & -0.043 \\
\hline Implementers & 0.75 & 0.41 & 0.55 & 0.41 & 0.23 & 0.006 \\
\hline Universities & 0.66 & 0.57 & 0.17 & 0.11 & 0.10 & 0.001 \\
\hline Offices & 0.65 & 0.49 & 0.25 & 0.16 & 0.12 & 0.026 \\
\hline \multicolumn{7}{|c|}{ Average } \\
\hline
\end{tabular}

Source: Author's own study.

It is worth noting that among the respondents a very similar distribution of results was found in the perception of the attributes of urgency and legitimacy. From the point of view of the Implementers, Firms, and Agencies, the project completion was very urgent and they accepted the need to extend the GSTP to a large extent (legitimacy). For the people from the other three groups of stakeholders, namely Residents, Universities, and Offices, the project implementation date was unimportant and they had no opinion in terms of its acceptance. From the point of view of social benefits, the vast majority of positive indications appeared among people from the following two groups: Implementers and Companies. The least number of indications was from the Offices. The social costs of the project were most often pointed out by Residents and Universities.

Table 2. Average response values in stakeholder groups

\begin{tabular}{|l|c|c|c|c|c|c|}
\hline \multicolumn{1}{|c|}{ Stakeholders } & Attitude & Power & Urgency & Legitimacy & Benefits & Costs \\
\hline Agencies & 4.5 & 4 & 4.3 & 4.4 & 4.2 & 2.3 \\
\hline Firms & 4.9 & 2.8 & 4.7 & 4.2 & 4.5 & 3.1 \\
\hline Residents & 3.9 & 1.9 & 3.5 & 3.3 & 4.0 & 3.7 \\
\hline Implementers & 4.9 & 4.9 & 5.0 & 4.9 & 4.6 & 2.6 \\
\hline Universities & 4.3 & 1.9 & 3.5 & 2.9 & 4.0 & 3.3 \\
\hline Offices & 4.3 & 1.8 & 3.8 & 2.8 & 3.9 & 3.2 \\
\hline
\end{tabular}

Source: Author's study. 


\section{Conclusions}

The results obtained, in the form of a value of the index of social benefits and costs (ISBC) in the amount of 0.06 , indicated an advantage of social benefits over the social costs of the GSTP extension project and, consequently, the need to include them in the valuation of the project.

At the same time, taking into account the results of the survey, the stakeholders reacted positively to the implementation of the project, emphasizing the creation of new, highly specialized jobs and the increase of the region's technological potential and implementation of the results of scientific work. Additionally, it is important to emphasize the active role of the residents stressing the elimination of flooding in the areas around the GSTP.

It should also be mentioned that the task of the GSTP's management (i.e. the Pomeranian Special Economic Zone Ltd., of which the GSTP is a part) should be the development of appropriate communication with stakeholders. The initiation of joint activities between entrepreneurs, business support institutions, and universities may in fact result in lasting cooperation in the implementation of innovative projects, as well as contribute to the achievement of strategic goals of the GSTP.

\section{References}

European Commission (2006). Guidance on the Methodology for Carrying out Cost-Benefit Analysis.

Florio, M. (2008). Guide to Cost-Benefit Analysis of Investment Projects. Structural Funds, Cohesion Fund and Instrument for Pre-Accession. European Commission.

Freeman, R.E. (1984). Strategic management: A stakeholder approach. Journal of Management Studies, 131-154. doi:10.1017/CBO9781139192675

Freeman, R.E., \& Reed, D.L. (1983). Stockholders and shareholders: A new perspective on corporate governance. California Management Review, 25, 88-106. doi:10.2307/41165018

Freeman, S.C., Harrison, J.S., \& Wicks, A.C. (2007). Managing for Stakeholders: Survival, Reputation, and Success. New Haven: Yale University Press.

Kozłowski, W. (2012). Zarzadzanie gminnymi inwestycjami infrastrukturalnymi. Warszawa: Difin.

Mitchell, R.K., Agle, B.R., \& Wood, D.J. (1997). Toward a theory of stakeholder identification and salience: Defining the principle of who and what really counts. The Academy of Management Review, 22(4), 860-862. doi:10.2307/259247

Olander, S. (2007). Stakeholder impact analysis in construction project management. Construction Management and Economics, 25(3), 277-287. doi:10.1080/01446190600879125

Piontek, B., \& Piontek, F. (2007). Zarządzanie rozwojem: aspekty społeczne, ekonomiczne i ekologiczne. Warszawa: PWE.

Rybak, M. (2007). Etyka menedżera - społeczna odpowiedzialność przedsiębiorstwa. Warszawa: PWN.

Savage, G.T., Nix, T.W., Whitehead, C.J., \& Blair, J.D. (1991). Strategies for assessing and managing organizational stakeholders. Academy of Management Perspectives, 5(2), 61-75. doi:10.2307/4165008

Ward, S., \& Chapman, C. (2008). Stakeholders and uncertainty management in projects. Construction Management and Economics, 26(6), 563-577. doi:10.1080/01446190801998708

World Bank. (2006). Multi-stakeholder dialogue. Communication for Governance \& Accountability Program. Washington, DC: World Bank. Retrieved from http://siteresources.worldbank.org/EXTGOVACC/Resources/MultiStakeholderweb.pdf [access: 1.05.2019]. 